openUP

\title{
ALTERNATIVE MONETARY SYSTEMS AND THE QUEST FOR STABILITY: CAN A FREE BANKING SYSTEM DELIVER IN SOUTH AFRICA?
}

\author{
ADRIAN SAVILLE, MAUREEN BADER, AND ZANE SPINDLER
}

Once in a while you will stumble upon the truth but most of us manage to pick ourselves up and hurry along as if nothing had happened.

Winston Churchill

\begin{abstract}
Since the early 1900s central banking has developed into the most widely adopted monetary regime by sovereign states. Yet, there is a broad raft of evidence which shows that central banking systems have been less successful in delivering macroeconomic stability than alternative monetary systems. The argument is pronounced in the case of emerging economies, a set of countries which includes South Africa. Against this backdrop, this paper reviews the case for central banking in South Africa. Our results lead us to explore various alternatives to central banking, including Dollarisation and monetary union. However, because these systems are not without their own vulnerabilities, we consider a third alternative regime, free banking. We argue that, despite being an almost completely forgotten system, free banking has the capacity to improve South Africa's monetary system and enhance the country's macroeconomic stability.
\end{abstract}

\section{INTRODUCTION ${ }^{1}$}

Since the early 1900s, most sovereign states have adopted the central bank model as their monetary regime. Although the model has been successful in places, particularly in recent decades, it is also the case that, with time, weaknesses in the model have become evident. This has caused an increasingly vigorous debate devoted to identifying ideal monetary regimes and the optimal national and international financial architecture (de Vanssay, 2002; Frankel, 1999; Stockman, 2000). The literature on money, banking and financial systems has given attention to two main alternatives to central banking, namely Dollarisation and monetary union. In the case of South Africa, however, writers have tended to focus on exploring policy revisions within the extant financial architecture of central banking (Aron and Muelbauer, 2004; Bhundia and Gottschalk, 2003; Mollentze, 2000). As a result, with a few exceptions, the literature has paid almost no attention to considering the worth of alternatives to South Africa's central banking model (Khamfula and Mengsteab, 2004; Wessels, 2003).

\footnotetext{
${ }^{1}$ The authors wish to thank Xavier de Vanssay, Brian Dollery, Herbert Grubel, Kerry Hadfield, David Hammes, Brian Kantor, Chikara Komura and Roger Sandilands for comments and editorial suggestions on previous drafts of this paper; the authors also are grateful for the useful suggestions provided by two anonymous referees which helped to improve the paper. The usual caveats apply.
} 
This gap in knowledge demands attention given that experiences elsewhere in the world highlight the vulnerabilities of the central banking model in the case of a small, open, emerging economy, such as South Africa. ${ }^{2}$

Against this backdrop, and using an historical context to explore the arguments, this paper examines whether the central banking model is the best monetary system for South Africa. On this point, it must be recognised that assessing the desirability of monetary systems is a broad theme, which embraces a diverse set of topics that includes price stability, exchange rate stability, efficiency of the banking system and the promotion of economic growth. This paper explores these arguments with an emphasis placed on the achievement of banking sector stability as a necessary condition for the achievement of stability in price inflation and the promotion of economic growth. This focus is in line with the SARB's policy stance, which focuses on price stability but places a secondary emphasis on economic growth. However, it must be recognised that the inter-relatedness of macroeconomic variables means that some consideration is given to related issues such as exchange rate stability. That aside, our findings suggest that the central banking model is not the best model for promoting the objectives of monetary stability and, in particular, price stability, and the result extends to South Africa. Based on the arguments presented, the paper goes on to consider the potential benefits of alternatives to the central banking model.

In section 2 we consider, briefly, the history of South Africa's monetary system, including the development of the central banking system since the mid-1920s. In section 3, we review global data to examine the efficacy of central banking. The findings suggest that alternatives to central banking potentially offer more effective national monetary systems. Accordingly, sections 4 and 5 explore the feasibility of two of the most widely examined alternatives to central banking, Dollarisation and monetary union. An emphasis is placed on the feasibility of adopting these systems in South Africa. However, whilst arguably more robust than the central banking alternative, these alternatives suffer fundamental weaknesses which potentially are overcome through the adoption of a historically important - but recently neglected -alternative system, namely free banking. From this basis, sections 6 and 7 consider the free banking alternative, and the feasibility of its adoption in South Africa.

\section{THE HISTORY OF SOUTH AFRICA'S MONETARY SYSTEM}

\section{(a) South Africa before Central Banking}

Between 1837 and 1921, a system widely known today as free banking guided commercial banks in South Africa (Dowd, 1992). Free banking is commonly defined as a banking system in which there is no government intervention with respect to the quantity of money, no legal barriers to entry or branching, no restrictions on assets, liabilities or capital of banks, no interest rate controls, no central bank and no deposit guarantees. ${ }^{3}$ Thus, in free banking systems, commercial banks issue notes bearing the issuing bank's name, and this was the case in South Africa under free banking.

${ }^{2}$ Various critiques are explored elsewhere, for example see Demertzis, Hallett and Viegi (2004), Dowd (1992), Grubel (2003, 2004), Selgin (1996) and Thomas (2000).

${ }^{3}$ See Selgin and White $(1994,1718)$ and Hickson and Turner $(2004,903)$ where the definition of free banking is discussed. 
The issued notes were backed by paid-up capital and gold reserves, and were convertible into gold specie. An extensive branch system promoted bank stability, and by 1910 the South African economy boasted seven issuing banks (Henry, 1963:114). Furthermore, despite the rapid growth experienced over the late 1800s and early 1900s, the banking system exhibited extraordinary stability as, 'in the interest of the banking system as a whole, the stronger often came to the help of the weaker' (Henry, 1963:112).

But, like many other countries at the time (witness the introduction of 'nonconvertability' elsewhere), the events following the First World War led to dramatic change in South Africa's banking system. Prior to the outbreak of the war, the South African economy accounted for almost half of the world's gold output. At that time, the gold standard prevailed, and London was the world's financial centre. For this reason the Bank of England made arrangements with South African gold mining companies to ensure control of gold production during the war years. But, during the war, Britain abandoned the gold standard, Sterling devalued and South Africa experienced a significant outflow of specie. In turn, South African commercial banks, which were forced to redeem notes into specie at a lower value than their cost of replenishment, lobbied government for the right to issue nonconvertible notes. From this set of events, the idea of a central bank was promoted by the South African Union's Secretary of Finance in late 1919 and, although opposition existed (De Kock, 1954:18), in sympathy with international pressure, the South African Reserve Bank (SARB) was established by the Currency and Banking Act of 1920. From these origins, the central bank model has come to play the prime role in the South African banking system since 1920.

\section{(b) South Africa under a Central Hank}

The first governor of the SARB was W.H. Clegg, whose primary goal was to establish and maintain reserve bank independence, consolidate note issuance and work towards reestablishing the gold standard (Ally, 1994:97-101). South Africa enjoyed success in rejoining the gold standard in 1925 (De Kock, 1954:78), but this relationship ended in 1932, following Britain's abandonment of convertibility in late 1931 and the domestic bank run that resulted from a political threat in late 1932 to 'go off gold' (De Kock 1954:188). Thus, by the end of 1932 notes had become legal tender and the Minister of Finance announced that 'the Union had completely cut the link with the gold standard' (De Kock 1954:161-163). At the same time, Clegg had warmed to the idea of direct government involvement in central banking (Ally, 1994:95). In sympathy with this vein of thought, during and shortly after the Second World War, like many other central banks, the SARB came to closely pursue the debt financing interests of the South African government. Although hardly conclusive, this episode in South Africa's central bank history demonstrates that no central bank can ever be independent, in the ultimate sense, from governments and that factions influence governments (Meltzer, 2005).

In any event, under the influence of the Keynesian revolution, the SARB embarked on a more independent path, becoming more active in its attempts to manage monetary policy during the 1950s and 1960s (Greenspan, 2005:137). Some policy successes were achieved. Over the course of the 1960s, consumer price inflation averaged 2.4 per cent per annum (see Fig. 1). However, from about the middle of the 1960s, the SARB reverted to using monetary policy as a tool to support fiscal policy. Consequently, inflation climbed to an annual average of 9.6 per cent per annum during the 1970s, 
reaching 15.2 per cent in the early part of the 1980s. Significantly, over this period, the SARB's attempt to control the money supply were directly - relying on inter alia credit ceilings, deposit rate controls and reinforced foreign exchange controls (which had been introduced in South Africa during the Second World War as a means of protecting the country's foreign exchange reserves) - rather than being market based.

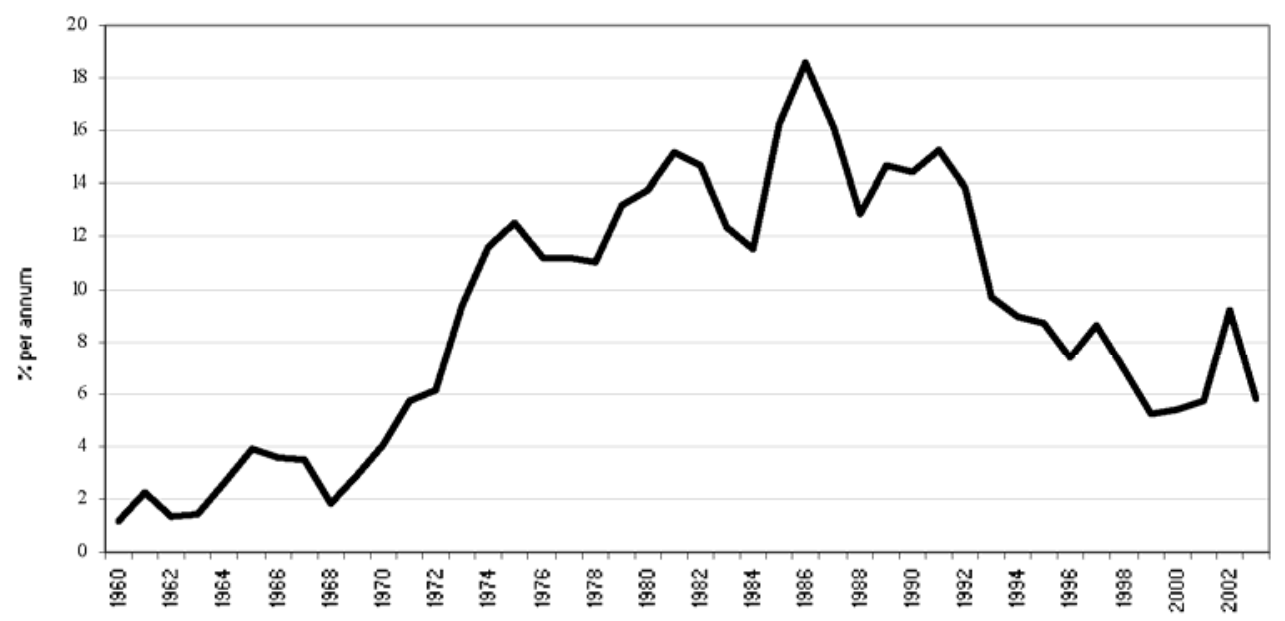

Figure 1. Consumer Price Inflation (1960-2004)

Source: Adapted from data provided by Statistics South Africa

Again, following global trends, the early 1980s saw monetarist thinking gaining a foothold in South Africa, and the reserve bank moved towards a more market-based system of monetary intervention, with emphasis placed on controlling price inflation. However, the focus on inflation was crystallised by the financial crisis of 1985 which was precipitated by the huge capital outflows that followed the political unrest of 1984 and 1985. These capital outflows forced the South African government to enter into a partial debt standstill. Panic selling of the Rand in August 1985 led to the SARB closing foreign exchange markets for four days. Despite this intervention in the currency market, the Rand collapsed, causing consumer price inflation to soar in 1986. Thus, it is arguable that, by the second half of the 1980s, the bank had become convinced that'... inflation is everywhere and always a monetary phenomenon' (Friedman, 1992:193).

Between the latter half of the 1980s and the early years of this century the SARB continued to focus on lowering inflation using market-oriented monetary policies, and these efforts enjoyed some success. However, relatively greater success in controlling inflation has been achieved since the adoption of an official inflation target by the SARB in early 2000, with the target range set at three per cent to six per cent per annum. ${ }^{4}$ Nevertheless, whilst the SARB has achieved some success since adopting targeting, this success has been partial (see Fig. 2).

Despite the SARB having been only partially successful in achieving the inflation target since 2000, the bank has enjoyed growing professional approval. For instance, Aron and Muelbauer (2004:47) note: 'There is clear evidence of a gain in credibility and an anchoring of inflationary expectations under targeting'. Yet, as we argue below,

${ }^{4}$ The target is based on inflation measured by the consumer price index free of the inflationary influence of interest rates on mortgage bonds (CPIX). 
South Africa's adoption of central banking, and the growing affinity for the model, demands examination because of the existence of robust theoretical arguments and a substantial body of evidence which suggest that the central bank model is far from optimal. ${ }^{5}$ We expand on these concerns in section 3 .

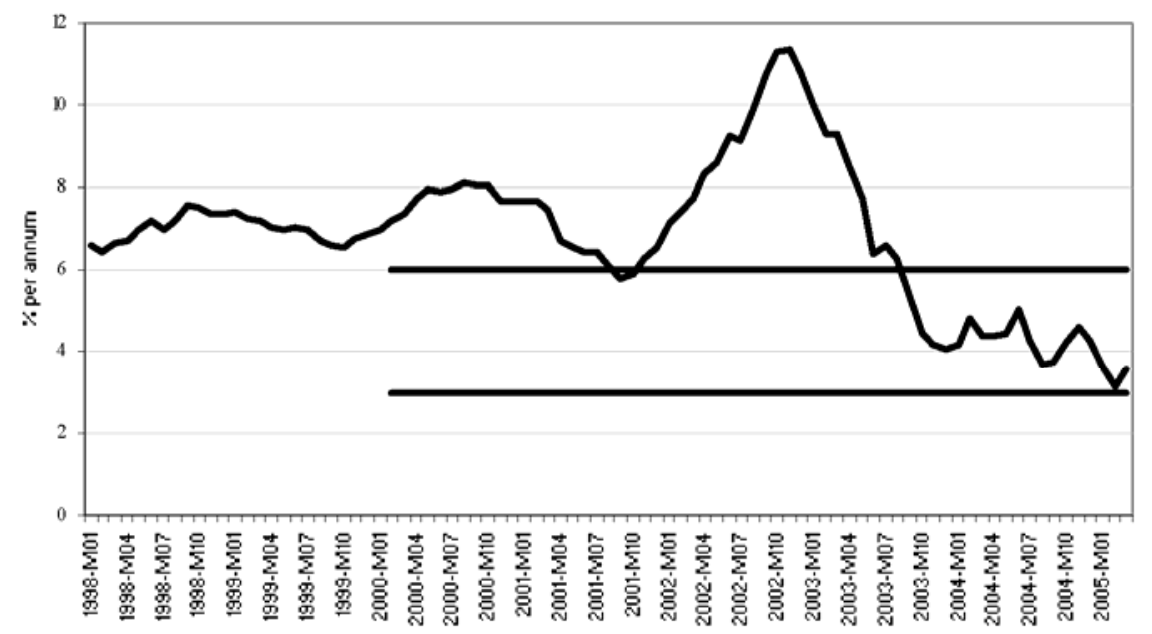

Figure 2. CPIX Inflation and Inflation Targets (1998-2005)

Soure: Adapted from data provided Statistics South Africa

\section{CONSIDERATION OF THE EFFICACY OF A CENTRAL BANKING REGIME}

(a) Central Banking and Economic Stability: A. 'Review of the Empirical Evidence Before exploring theoretical concerns about the central banking model it is appropriate that we examine the empirical evidence, as the outcome has bearing on the South African case. On this score, a recent study sampled data from more than 200 countries over a 30-year period to assess these countries' success in achieving macroeconomic stability (Gwartney, Schuler and Stein, 2001). In this analysis, three metrics for stability are employed, namely low rates of price inflation, high rates of economic growth and exchange rate stability. Importantly, the sample includes developed and emerging economies with and without central banks. ${ }^{6}$ The results of the analysis are shown in Table 1.

As the evidence demonstrates, the ability of emerging countries with central banks to achieve stability has been poor, while emerging countries without central banks have fared as well as developed countries with central banks. Specifically, emerging economies with central banks have been characterised by high or exceptionally high rates of price inflation; foreign exchange controls and above-average currency depreciation; and low rates of economic growth.

In contradistinction, emerging economies without central banks have enjoyed greater macroeconomic success.

\footnotetext{
${ }^{5}$ The literature dealing with the topic is extensive. Here, we restrict the discussion to criticisms that are directly relevant to the central thesis of this paper.

${ }^{6}$ Note that the source for economic growth and inflation rate data has some omissions. Also, results are not weighted by size of the economy.
} 


\begin{tabular}{|c|c|c|c|}
\hline & $\begin{array}{l}\text { Developed Countries } \\
\text { with Central Banks }\end{array}$ & $\begin{array}{l}\text { s Emerging } \\
\text { Economies with } \\
\text { Central Banks }\end{array}$ & $\begin{array}{l}\text { Emerging } \\
\text { Economies with } \\
\text { Other Monetary } \\
\text { Systems7 }\end{array}$ \\
\hline \multicolumn{4}{|c|}{ Average annual consumer price inflation (1971-1998) (per cent) } \\
\hline Mean & 8.9 & 79.7 & 11.8 \\
\hline Median & 5.4 & 10.8 & 8.7 \\
\hline Standard deviation & 19.7 & 702.4 & 17.4 \\
\hline \multicolumn{4}{|c|}{ Countries experiencing inflation exceeding 20 per cent per year (1971-2000) } \\
\hline Percentage & 16 per cent & 59 per cent & 13 per cent \\
\hline Absolute number & 8 of 36 & 86 of 145 & 8 of 64 \\
\hline \multicolumn{4}{|c|}{ Countries experiencing inflation exceeding 100 per cent per year (1971-2000) } \\
\hline Percentage & 0 per cent & 22 per cent & 0 per cent \\
\hline Absolute number & 0 of 36 & 32 of 145 & 0 of 64 \\
\hline \multicolumn{4}{|c|}{$\begin{array}{l}\text { International Monetary Fund (IMF) member countries with exchange controls on current account transactions as at en } \\
1999\end{array}$} \\
\hline Percentage & 18 per cent & 67 per cent & 20 per cent \\
\hline Absolute number & 6 of 34 & 91 of 136 & 3 of 15 \\
\hline \multicolumn{4}{|c|}{ Exchange rate depreciation against US Dollar or official anchor currency from 1971 or date of first issue to end 20008} \\
\hline Percentage & 72 per cent & 94 per cent & 3 per cent \\
\hline Absolute number & 26 of 36 & 133 of 141 & 1 of 31 \\
\hline \multicolumn{4}{|c|}{ Average annual gross national product (GNP) growth per person (1971-1998) (per cent) } \\
\hline Mean & 2.1 & 1.1 & 1.8 \\
\hline Median & 2.3 & 1.6 & 1.9 \\
\hline Standard deviation & 6.1 & 7.0 & 6.6 \\
\hline
\end{tabular}

Soure: Gwartney et al. (2001:196)

For instance, over the past 30 years, emerging economies without central banks have grown almost as rapidly as the world's most advanced economies, and materially quicker than emerging economies with central banks. The above argument is supported by the existence of a mean rate of economic growth in emerging economies without central banks of 1.8 per cent versus that for emerging economies with central banks of 1.1 per cent. However, the mean is a fragile statistic, easily distorted by outliers; for this reason it is more meaningful to consider the median as a basis for comparison. Using this metric it remains the case that the economic growth performance of emerging economies without central banks exceeds that of emerging economies with central banks. Similarly, the median rate of inflation in emerging economies without central banks of 8.7 per cent is lower than the 10.8 per cent recorded by emerging economies with central banks. It is also notable that the set of emerging countries without central banks - which includes economies as diverse as Ecudaor, El Salvador, Guam, Guatemala, Panama, Puerto Rico, Samoa and the Virgin Islands - did not experience a single instance of hyperinflation over the sample period. Over the same period, almost one-third of emerging economies with central banks experienced hyperinflation, and endured a median rate of price inflation that was twice that of advanced economies. Similarly, the currencies of emerging economies without central banks exhibited above-average strength in the absence of foreign exchange controls. This result sharply contrasts with outcomes in emerging economies with central banks, where exchange controls have invariably been applied to achieve stability but apparently with little success.

In short, history suggests that, on balance, emerging economies that have adopted

\footnotetext{
${ }^{7}$ The sample excludes former Soviet republics that briefly used the Russian rouble in 1991 and 1992 before issuing their own currencies.

${ }^{8}$ The sample includes the US Dollar, which depreciated against gold.
} 
central banking systems have failed to achieve macroeconomic stability. In contrast, emerging economies that have adopted alternative monetary systems evidently have succeeded in achieving stability. Thus, two questions arise. First, does the central banking system suffer from weaknesses or vulnerabilities that are greater than alternative systems, or would countries that fared poorly have also struggled to achieve stability under alternative regimes? Below, we argued that central banking suffers inherent weaknesses that alternative regimes are effective in countering. Thus, and secondly, given the poor track record of central banking, why have so many countries, including South Africa, pursued the regime? This question is also addressed below.

(b) Central Banking and Economic Stability: Some Theoretical Concerns

Whilst the evidence presented above suggests that central banking has been no more than partially successful in promoting macroeconomic stability, the result only has bearing on the efficacy of the monetary system if it can be demonstrated that central banking suffers from inherent weaknesses that are less evident or, ideally, absent in alternative systems. To this end, the available literature, which enjoys widespread acceptance, devotes considerable attention to the merits, strengths and advantages of central banking. However, some writers argue that the central bank model is vulnerable to weaknesses. Because of constraints of space and time, we identify three core vulnerabilities that are arguably common to all central banking systems.

First, the central banking model requires the reserve bank to act as a smooth functioning absorber of economic shocks. However, evidence suggests that economic shocks cannot be anticipated with great accuracy (Grubel, 2003; Meltzer, 2005). As a consequence, banks tend to respond to shocks with a lag. Grubel (2004) shows this type of reaction often delays and sometimes prevents economies from making appropriate long-run adjustments. Second, although central banks have come to recognise the sophistication of markets (Blinder, 2004), poor forecasting abilities (Meltzer, 2005; Nofsinger, 2001; Stamp, 2002) and a collective presumption of superior intelligence on behalf of central banks have potentially 'intractable' outcomes such as a belief that markets can be 'trained' (DeLong, 2004; Meltzer, 2005). Hayek (1988) referred to this notion as 'the fatal conceit', as it encourages perverse central bank behaviour. Third, policy influences are never immediate. Rather they last for extended periods; and this makes near-term reversal of policy effects difficult if not impossible (see, for example, Meltzer, 2005). However, the confounding factor is that as long as central banks are a creature of the state it is difficult to expect politics not to play a role in monetary policy (Vaubel, 1997). For this reason, reserve bank independence is an important aspect of any effective central banking regime (Barro and Grilli, 1994). However, even where banks enjoy independence in influencing instruments, such as interest rates and money supplies, they often do not enjoy independence in setting goals. Witness the South African case (Mboweni, 2004:4):

"Our inflation target is set by [GJovernment after consultations between the Bank and the National Treasury have taken place. Thus the Bank does not have autonomy in choosing the inflation target and as such does not have goal independence. The Bank, however, has complete independence in making monetary policy decisions aimed at achieving the target."

Moreover, the available evidence suggests that even where banks enjoy instrument and goal independence, the central banking system remains subject to a lack of public accountability of central bankers; this is what Du Plessis (2005) calls the 'democratic 
deficit'. In short, true central bank independence is an exceptional outcome (Demertzis, Hallett and Viegi, 2004:907) with the evidence suggesting that independence exists in degrees, if at all (Barro and Grilli, 1994).

Thus, the theoretical literature puts forward a number of challenges to the central banking model. Moreover, the evidence presented earlier suggests that emerging economies with central banks have performed poorly compared to other emerging economies without central banks and developed countries with central banks. Read against this backdrop, it is evident that the central banking model is vulnerable to weaknesses, which are arguably most pronounced in the case of emerging economies. Given South Africa's, status as an emerging economy and the country's reliance on the central bank model, the remainder of this paper is devoted to exploring alternatives to central banking, with an emphasis on the potential for adoption of alternative models in South Africa. Specifically, we devote attention to considering the alternative models that have enjoyed the greatest attention in the literature and practice, namely Dollarisation and monetary union. Because of our findings, we go on to consider a third, recently neglected, alternative to central banking, free banking.

\section{DOLLARISATION}

Of the alternatives to central banking identified, the academic literature has given the greatest attention to Dollarisation in the context of emerging economies (Salvatore, Dean and Willett, 2003). In effect, Dollarisation entails substitution of the domestic currency with a 'hard' currency, and the US Dollar is typically identified as the currency of preference. In practice, this currency substitution is achieved either by engaging a currency board that maintains a stock of hard currency sufficient to redeem (at a fixed ratio) the entire stock of local currency (such as Hong Kong), or through adopting the hard currency as 'legal tender' (Panama) (Bogote, 2000).

The literature identifies a number of potential benefits of Dollarisation (Selgin and White, 2005). To start with, the adoption of a 'hard' currency ensures monetary policy discipline as governments cannot monetise their debts. Market forces determine the quantity of money, and monetary adjustment occurs automatically with excess money being invested outside of the economy. Thus Dollarisation promotes monetary and price constancy by importing economic stability. Beyond this, Dollarisation replaces the central bank as lender of last resort by harnessing the international banking system as lender of last resort. The case of Panama illustrates the point, where, at the end of 2004 more than 50 international banks operated offices in that country. Further, during Panama's economic crises of 1964, 19671969, 1973-1975 and 1978-1980 foreign banks used external funds to support their local operations. Effectively, then, the home offices of international banks functioned as lenders of last resort (Moreno-Villalaz, 1999).

Furthermore, under Dollarisation, financial supervision is conducted by the international private banking sector through the purchase of government bonds, with investment ratings inferred from this pricing activity. Interestingly, the investment ratings achieved by Dollarised countries suggest that the market has achieved effective financial supervision under Dollarisation (Balino, Bennett and Borensztein, 1999). However, possibly the most important benefit of Dollarisation is that it prevents governments from expropriating wealth through price inflation and foreign exchange controls. 
Yet, arguably, there are costs to Dollarisation, which include the loss of seigniorage, the disappearance of a vehicle for national symbols, diminished monetary policy flexibility and a loss of a lender of last resort (Berg and Borensztein, 2003; Selgin and White, 2005). These costs are examined below.

The first cost of Dollarisation is the loss of seigniorage, which is revenue that a government receives by issuing money. To be more exact, because governments or their central banks do not have to pay interest on their currency, they earn revenue (seigniorage) by using this currency to purchase income-earning assets such as bonds. If an economy Dollarises it needs to make up the loss of revenue; this is particularly difficult for less developed economies. That said, it is hardly efficient for the economy to have the cost of government hidden or to have a government's command over resources enhanced by an unlegislated, hidden tax on money balances (Spindler, 2004a). Accordingly, it is arguable that whilst Dollarisation translates into a loss of seigniorage, this cost is possibly overstated as well as misperceived.

A second cost of Dollarisation is the loss of a vehicle for the promotion of national symbols. This is considered to be a political cost. However, from unofficial Dollarisation it is evident that a country's currency unit is often disposed of as soon as it becomes apparent that the national symbol is a victim of the negative effects of the actions of monetary authorities. Moreover, according to Hanke $(1999,408)$, '... the several Dollarised countries that are independent do not find that Dollarisation constrains their independence, or that a locally issued currency is essential to sovereignty or to national pride'.

Third, Dollarisation results in a loss of flexibility in monetary policy, and this point cannot be disputed. However, as Table 1 infers, this loss of flexibility may benefit emerging economies without central banks, as these countries have enjoyed higher growth rates and lower inflation rates than emerging economies with central banks that have a higher degree of flexibility in conducting monetary policy. But this outcome is hardly surprising: when the exchange rate is truly fixed, as it is in the case of Dollarisation, governments are forced to maintain fiscal responsibility while macroeconomic variables, such as price inflation, have to respond. Thus, the loss of monetary flexibility is arguably an advantage, rather than a disadvantage.

Fourth, it is argued that Dollarising countries lose access to their own central bank as a lender of last resort (LOLR). As is the case with monetary policy flexibility, this outcome cannot be disputed. But, it is far from settled that this is a cost to the Dollarising economy. Central banks that engage in rescuing failed banks become enmeshed in an expensive activity. Resolving the banking crisis in Argentina in 1980-1982 is estimated to have cost the equivalent of 55 per cent of that economy's gross domestic product (GDP) (Hanke, 1999:409). Moreover, the presence of a lender of last resort does not preclude banks from failing, as South Africa's recent experience with the failure of Saambou Bank Limited demonstrates (Vercuil, 2002). Too often, historically, central banks have failed to fulfil the LOLR function, because it is not automatic but discretionary.

Fifth, a potential problem with Dollarisation is that the adopting economy has to adapt to the different relationships that might exist between the adopted currency and the currencies of different trading partners. Thus, relatively open, emerging economies with high ratios of foreign debt denominated in other currencies may face significant adjustment problems after Dollarisation. In theory the adoption of an overvalued 
currency should lead to lower domestic prices, but that adjustment may not occur quickly, if ever.9 With slow or no domestic price adjustment, this fifth, 'relative value' cost of Dollarisation may not be automatically mitigated.

Thus, Dollarisation is not without potentially negative impacts. However, the arguments presented above suggest that these impacts generally are overstated. Furthermore, Dollarisation allows an emerging economy to gain, in a short space of time, a monetary system that enjoys a high level of stability and a globally competitive risk premium (Grubel, 2003 and 2004; Spindler, 2004a). Dollarisation also precipitates abandonment of active monetary policies and facilitates abolition of growth-depriving foreign exchange controls. These points are effectively demonstrated by the case of Panama, which Dollarised in 1904. Between 1961 and 2004, Panama had an average annual rate of price inflation of 2.7 per cent, compared to over 10 per cent for the rest of Latin America and over 1000 per cent for Argentina and Brazil. ${ }^{10}$ Thus, a case can be made for the adoption of Dollarisation in emerging economies, where policy makers are grappling with the task of achieving macroeconomic stability, particularly where their efforts are hampered by 'extraneous' factors such as foreign exchange controls. Importantly, the practical obstacles to Dollarisation are modest -although consideration must be given to addressing the potentially disruptive and harmful cost of Dollarisation caused by the relative value effect identified above. We return to the case for Dollarisation below. First, however, we consider the second alternative system to a sovereign central banking regime, namely monetary union.

\section{MONETARY UNION}

Monetary union is a situation in which several countries agree to share a single effective currency, a single monetary policy and a single effective exchange rate, with formal union taking place under one of four possible regimes (de Vanssay, 2002:28):

(i) a supra-national, union-wide central bank (such as the European Central Bank)

where the shareholders are the national central banks of the countries making up the union;

(ii) a single central bank for all members of the union (such as Switzerland and Liechtenstein's solution, with the central bank located in Switzerland);

(Hi) more than one multinational central bank (such as the Franc zone in Africa which has two multinational central banks); or

(iv) no multinational central bank(s), but multiple national central banks (for example, the Latin monetary union between France, Belgium, Switzerland, Italy and Greece [1865-1920]).

9 Schuler (2005) provides evidence that after passing its "Convertibility Law", there was domestic price adjustment in Argentina to prevent its currency from being overvalued, on balance, relative to its trading partners - contrary to the presumptions of many prominent economists who had failed to analyse the evidence.

10 On a more practical level, fervent opposition to Dollarisation endures as a result of Argentina's failed experiment with Dollarisation and subsequent de-Dollarisation at the beginning of 2002. However, it has been effectively shown that this conclusion is based on a misreading of the evidence (Hanke, 2003a; Murphy, Artana and Navajas, 2003:24, Schuler, 2005). In fact, Argentina had actually not Dollarised, and, indeed, did not even have a standard currency board. Rather, the central bank was subject to the "Law of Convertibility" between April 1,1991 and January 6, 2002, where one peso was set equal to one US Dollar. 
The first of these solutions - exemplified by the European Economic and Monetary Union (EMU), which exists between 12 of the 25 member states of the European Union that have adopted the Euro as their single currency - is the most common form of monetary union. For this reason we focus our attention on this type of monetary union.

Quintessentially, under a supra-national arrangement, union results in monetary policy moving out of the control of the sovereign state to become centrally coordinated. From this basis, as with Dollarisation, monetary union is argued to provide a suite of economic benefits vis-a-vis central banking (Hanke, 1999). First, the governments of members of a monetary union become committed to a monetary rule, and sovereign political discretion over monetary policy is effectively removed. Evidence shows that this results in lower country risk premiums, reduced exchange rate risk, lower price inflation, lower real interest rates and higher rates of economic growth (Bader and Spindler, 2005). Second, unionising countries benefit from enhanced investment flows and greater trade flows as a result of lower exchange rate volatility and reduced transaction costs (Rose, 2000). Third, and less self evident, is the benefit to taxpayers brought about by the stability of monetary unions (Hanke, 1999, 409). Fourth, in some forms of union the administrative costs of running a central bank can be reduced or even eliminated at the country level, although this is not the case in all forms of union.

Of course, monetary union may have potentially negative economic impacts, which include the loss of sovereignty and the loss of seigniorage (Schuler, 2003a). Considering the loss of sovereignty, it is self-evident that union results in a reduction in the sovereign status of money. But, as argued with Dollarisation, the loss of monetary sovereignty often turns out to be a benefit Hanke (1999, 408). Monetary union may also result in a loss of seigniorage; although some factors may moderate this outcome (see below) ${ }^{11}$

Despite these costs of union, the evidence suggests that, on balance, countries that move away from central banking by unionising enjoy net economic benefits (see Table 1, as well as Bader and Spindler, 2005). However, as unionisation is effectively a multilateral exercise, any country considering unionisation needs to contemplate the feasibility of entry into a monetary union. Given the context of this paper, we briefly consider these arguments by contemplating entry by South Africa into a monetary union using the relative credibility of the SARB and strength of the South African economy to develop the Rand as a common currency for Southern Africa.

Currently, South Africa is a part of the Southern African Customs Union (SACU), which embraces Namibia, Swaziland, Botswana and Lesotho (McCarthy, 2003). Notably, Namibia, Swaziland, and Lesotho's currencies are pegged to the Rand, and the Botswana Pula is pegged to a basket of currencies composed of special depository receipts (SDRs) and the Rand (Khamfula and Mengsteab, 2004). Also, SACU members enjoy revenue sharing arrangements which, when coupled with their close currency associations, suggest that expanding the use of the Rand as the monetary unit throughout the area would be a relatively easy first step towards a monetary union for that part of southern Africa.

\footnotetext{
${ }^{1}$ Monetary union may give rise to political problems. Whilst this consideration is beyond the scope of this paper, the issue is considered by, inter aha, Cohen (2003) and (1997).
} 
Ideally, however, common currency areas comprise countries that enjoy similar macroeconomic conditions, complemented by high factor mobility and trade integration. Khamfula and Mengsteab (2004) argue that the countries of southern Africa do not satisfy these conditions. But, rates of economic growth and price inflation in Namibia, Swaziland, Botswana and Lesotho benefit from their close ties with the South African economy (McCarthy, 2003:617), and this is promoted by increasing trade integration in the region. So, a case of growing homogeneity in economic conditions can be built. However, given that the long-standing SACU agreement has yet to bring about material convergence in economic structures of the member countries it is arguable that the problems associated with monetary union for these countries should not be underplayed. Notwithstanding this argument, South Africa enjoys the potential to enter into a common monetary arrangement with neighbouring countries, a point that is bolstered by Frankel and Rose's (1998) assertion that currency area optimality conditions are endogenous, and that unionisation promotes economic convergence.

Based on the arguments and evidence presented, Dollarisation and monetary union each hold the capacity to overcome the core weaknesses of central banking, namely the existence of moral hazards and the threat of political influence or interference. Although these alternative regimes are not without economic cost, they evidently are capable of delivering net economic benefits and each constitutes a workable alternative to central banking. However, effacing central banking with either of these two alternatives presents difficulties that are not immediately apparent.

In the case of Dollarisation, the system centres on the adoption of a single, strong currency which, ultimately, means that Dollarisation is anchored to the impulses of some central bank. Of course, history suggests that currencies like the Yen or the Dollar are likely to enjoy greater rather than less stability - certainly, we should anticipate that adoption of these currencies will engender more stability in emerging economies. However, history also reveals that even the most independent central banks are not immune from political pressures, political business cycles and the moral hazards identified by the public interest view (Friedman, 1982; Meltzer, 2005; Weintraub, 1978).

In the case of unionisation, the strength of the system is borne out of the multilateral status of the union's central bank which creates important checks and balances. However, the system is vulnerable to dissolution, and history reveals that fiscal and political union extremely difficult outcomes to achieve in their own right — are prerequisites to successful monetary union. Conversely, dissolution of monetary union can be expected to translate into a monetary system shock, currency volatility, banking system failure and, ultimately, economic catastrophe or, at least, an extreme undermining of the real economy.

Given these concerns, we turn our attention to the third alternative to central banking, namely free banking, a solution that goes beyond the adoption of a common or single currency and, in so doing, sidesteps the key vulnerabilities of Dollarisation and union. As we note below, however, it is feasible that a free banking system operates as an effective hybrid system by using the free banking model to capture the virtues and address the limitations of other systems, including Dollarisation and union. Thus, it should not be lost that Dollarisation, union and free banking are not necessarily mutually exclusive monetary systems. 


\section{FREE BANKING}

Free banking, as defined in section 2, refers to a banking system in which currency is issued by banks in their own capacity, with the bank's balance sheet and shareholder equity standing behind the currency. Further, given the absence of legal or regulatory barriers to entry, it follows that a free banking structure operates as a competitive system in which individual banks accept deposits (which may include their own currency, currency issued by other banks as well as currency issued by other countries, for example, a bank might accept US Dollar deposits). In return for these deposits, the bank will issue fully redeemable notes, which then act as currency. Redeemability ensures that issuing banks are disciplined by the ability to issue only 'fully backed' currency. However, as it is unlikely that all deposit holders will arrive at a given bank and demand redemption simultaneously, free banking essentially facilitates a fractional reserve system under which deposit taking banks make loans. As banks' deposit taking and lending activities grow, a clearing system ultimately develops that facilitates redemption. Beyond this, an essential feature of the free banking system is the built-in controls that limit excess creation of money because, sooner or later, all notes in circulation are equally likely to return to the issuing bank for redemption, and excess demand for redemption will eradicate a bank's reserves. For this reason, there is a propensity for individual banks to self-govern the note issuing process although, as we note below, this does not negate the need for a robust regulatory framework. Stability of the system is also bolstered by the growth of banks' branch systems, which facilitates diversification of loan portfolios. Of course, this dynamic can lead to an oligopolised industrial structure. However, because free banking allows people to hold whichever bank's currency they believe best protects their spending power and long-term economic interests, it does not necessarily lead to monopolisation or a lack of competitive constraint (Spindler and de Vanssay, 2000).

Free banking confers a range of economic benefits to the host economy. First, like Dollarisation, free banking eliminates the need for a central bank. However, unlike official Dollarisation, the system allows freedom of choice of financial institutions and currency units, and thus avoids the issues and challenges faced when using the currency of any one sovereign nation. Second, experience suggests that free banking has the capacity to substantially promote stability in monetary systems. By way of example, between 1791 and 1821 England experienced over 300 bank failures under a central bank, whilst, over the same period, neighbouring Scotland, under a free banking system, did not have a single bank failure (Dowd, 1992:181). The reason for this stability rests in the argument that governments are obliged to follow classical public finance principles, much the same as under monetary union or Dollarisation. Important to note, though, is that whilst free banking is synonymous with macroeconomic stability it does not imply an absence of bank failure. Rather, stability implies a low rate of failure. Support for this argument is provided, inter alia, by Rolnick and Warren (1983) in the case of the US, and Bader and Spindler (2005) in the case of Canada, Scotland and South Africa. ${ }^{12}$

Third, the benefit of microeconomic stability is also evident because, if a bank

\footnotetext{
${ }^{12}$ It is arguable that lack of cross-state branching ability meant that the antebellum period in the US was not a true example of free banking (for a more detailed distinction of free banking, see Briones and Rockoff, 2005).
} 
becomes insolvent, the private system is not obliged to lend to the failing bank. Thus, the affected bank will either go bankrupt or be bought out. In effect, confidence crises remain confined to the failing bank, rather than infecting the entire banking system. This argument is supported by the experience of Canada's free banking period (1817-1914) when the country's banking system did not suffer a single panic and, in contrast to experiences in regulated banking systems elsewhere, losses because of bank failure were insignificant (amounting to a nominal US\$3.3 million (Dowd, 1992,89; Chu, 1996). Fourth, the removal of the lender of last resort function of the central bank avoids the need for costly bailouts, such as those seen repeatedly in Latin American countries or the Savings and Loan fiasco in the US in the 1980s (Hanke, 2003b). Similarly, recent South African bank bailouts were not without public cost (Vercuil, 2002).

Benefits aside, the costs to the economy of free banking are similar to those under Dollarisation. For the sake of parsimony, these are simply listed here as including losses of government seigniorage, a vehicle for national symbols, monetary policy flexibility and a lender of last resort (Berg and Borensztein, 2003). Based on the same reasoning in the case of Dollarisation, these costs are ameliorated by various factors present under free banking although, as noted above, it must be recognised that the free banking model is not immune to vulnerabilities caused by market failures such as externalities, monopoly and information asymmetries which could give rise to a higher incidence of bank failures. But, as also noted above, the available evidence suggests that, on balance, free banking is effective in overcoming these vulnerabilities and, as such, presents itself as a monetary system that offers an alternative to the widely adopted central banking model and that has the capacity to confer net economic benefits in excess of those generated under central banking. Moreover, free banking circumvents the key vulnerabilities of both Dollarisation - by affording homecountry banks the ability to build reserves out of their currency of choice, rather than a single currency, and by eliminating the basis for political influence or pressure in the national banking system; and of unionisation - by avoiding the weaknesses of the unification of countries. However, given the patent advantages free banking enjoys over central banking, Dollarisation and union, this begs the question: 'If free banking is such a desirable monetary system, why is it not widely used?' The answer to this question can be found by delving into the economic history of free banking.

Although the system of free banking can be traced back to China at the turn of the last millennium, the origins of 'modern' free banking are in Scotland (1716-1844), and over the past three hundred years as many as 60 countries have engaged the system, with this set notably including South Africa, where the system was in place from 1837 to 1921 (Dowd, 1992:40-45). However, despite this relatively broad-based adoption, by 1935 free banking had effectively disappeared from modern economies (Dowd, 1992:37) to be replaced, in the main, by the central bank model. As Dowd (1992:46) notes, in most instances this outcome is explained by a combination of political motives and historical accident. For example, Canada's central bank was created in 1935 in order to inflate the economy out of depression (Briones and Rockoff, 2005:305). Our analysis suggests that the confluence of three key events explain the demise of free banking and emergence of central banking from the 1920s onwards.

First, from a public choice perspective, the success of free banking made the system an attractive source of revenue for governments. The US example provides a clear case 
in point where, over the course of the 1800s, US banks became a source of easy finance for state governments, which required individual banks to hold government bonds as part of their reserves; indeed, it is arguable that elements of the US banking system were designed specifically to promote the sale of government debt to banks (White, 2003:74). But at the same time, other benefits, such as seigniorage and a national symbol, were easily gained by the replacement of free banking with a government controlled central bank, which promoted the argument for central banking.

Second and not unrelated to the preceding point, events in the first part of the 1900s promoted populist sentiment in favour of loan expansion to governments on favourable terms. In particular, the First World War marked a turning point for monetary systems around the world under the heavy influence of inflationary war financing methods. As noted by Dowd (1992:36)

'After the [First World] War ... the League of Nations recommended that central banks be established in the new nations created after the war and in older countries. The League's recommendation proved influential.'

Even Canada introduced central banking, despite the fact that free banking had steered its financial system successfully through the early years of the Great Depression with no bank failures (Dowd, 1992:37).

Third, the possibility of central banking encouraged existing banks to look to government to legitimise (and, in the event of panic, subsidise) bankers' cartels that raised banks' profit rates by reducing effective working reserve ratios. There is an irony in this though, as shortly after its creation, the US Federal Reserve System failed to act effectively as a bankers' bank, and between 1930 and 1933 as many as 9000 US banks failed with depositors having no recourse to banks (Mishkin, 2000:250). ${ }^{13}$ The resulting financial collapse under this central bank experiment was much larger than any previously experienced without central banking. To boot, over the same period the Canadian free banking system did not experience a single bank failure (until the establishment of the Bank of Canada in 1935). Seldom do we find such 'natural experiments' that so definitively point out success and failure of alternative institutional arrangements. Nevertheless, the attractions of free banking were not appreciated at the time. Indeed, conclusions that opposed the evidence were drawn: the central banking failure was due to incomplete centralisation (Currie, 2004b). But this last result is not surprising as the events of the First World War and the Great Depression precipitated pressures favouring centralised control of the banking system. These forces enjoyed additional support from the general interest ideology of the time which held that central banks promote economic and monetary stability (Dowd, 1992:46; Currie 2004a and 2004b).

Widespread adoption of central banking was a natural outcome of these forces, with the result that over the past 75 years central banking has become the most widely adopted national monetary model. Despite this outcome, it remains the case that the evidence from economic history, as led in section 3, suggests that alternative systems may offer superior economic outcomes to the central banking model in emerging

\footnotetext{
${ }^{13}$ Recently, the Federal Reserve Bank's policy failure is most credibility attributed to its Governors' devotion to the Real Bills Doctrine, and the resulting passive central bank policy, after the death of Federal Governor Strong in 1928, who had previously pursued active price level stabilisation (Timberlake, 2005:196-233).
} 
economies. In the absence of contrary evidence, there is no reason to exclude South Africa from this group of countries. For this reason, we devote the final section of this paper to a consideration of the potential influences that different interest groups might have in implementing free banking in South Africa.

\section{FREE BANKING: A WAY FORWARD?}

Whilst support for and opposition to monetary system change is likely to arise at many levels, following Becker (1983), we identify below sources of influence favouring a move to free banking and forces opposing such a move. Considering the interest groups favouring free banking first, the international financial community would have an interest in promoting such a change as free banking would allow competitive entry into South Africa on 'national preference terms'. This might enjoy support from the local regulatory authority (presumably no longer the SARB) if a greater foreign bank presence was viewed as a complement to the stated 'four pillar policy' of maintaining (by merger prohibition) at least four major competing retail banks (Mboweni 2004:6).

Second, although South Africans would benefit from a free banking system that limited the ability of their government to levy inflation and money balance taxes and to regulate and tax their financial diversification internationally, it is arguable that the mass of citizenry would not find it in their interest to lobby for a change to free banking due to high individual costs of lobbying. But individuals and institutions whose financial portfolios are large enough to gain from a move to free banking after lobbying expenses - a small but powerful minority - could be expected to work in favour of such a shift. It follows that the remaining majority would free ride on the lobbying of this minority group. This coalition is most likely to succeed in its aims if the case for free banking is well understood by the public and the body politic.

Working in opposition to the above influences, South African banks whose operations are largely confined to South Africa may not favour increased competition from international banks. However, this opposition could be reduced if local banks recognised that free banking might ease their path to international expansion and diversification. Also, the entry of foreign banks could result in share prices improving on the basis of prospective and actual takeovers. Thus, domestic bank shareholders might find it in their interest to lobby for change, or at least free ride on the activity of other interest groups.

A second source of opposition would be the SARB management and staff who considered their livelihoods to be under threat. Such opposition could however be ameliorated by ensuring that these stakeholders benefited from the transition. This could be achieved, for example, by privatising the SARB with the above stakeholders becoming owners of the privatised bank. As shown by Spindler (2004b), the evidence from early United Kingdom privatisations shows that, with the right incentives, bureaucrats willingly participate in transformation. However, that is not always the case, especially when privatisations are not efficiently designed (Spindler, 2004b). In short, opposition from stakeholders in the SARB should be expected, but could be overcome.

Third, those who benefit from government employment and government transfers financed by inflation and money balance taxes might lobby in opposition to free banking. But, because revenues are fungible it may not be easy to identify which bureaucrats and/or beneficiaries would naturally consider themselves, on balance, to be threatened by a change to free banking. To the extent that such a change would result 
in more rapid economic growth, government revenues might increase sufficiently rapidly that the missing inflation and money tax revenues become more than offset by new revenue flows. Thus, this is one of those rare situations where the public interest is potentially served by a policy change that favours those with concentrated interests and prejudices those with dispersed interests, if indeed it prejudices anyone at all.

Fourth, the greatest opposition to free banking is likely to come from government itself. Amongst other things, free banking strips government of its ability to monetise deficits to generate seigniorage and to influence monetary policy and associated monetary factors - such as lending rates. Indeed, because central banks serve the interests of governments so well, it is likely that the greatest opposition to a move away from central banking will be from government. As economic history demonstrates, that free banking has become (almost) entirely eclipsed by alternative systems - particularly central banking - indicates that this source of opposition to change should not be underestimated in terms of its force or reach.

Indeed, when drawn together, it is evident that the forces opposing a shift to free banking potentially exceed those favouring such a move. This is unfortunate, given the patent advantages free banking enjoys over central banking. Perhaps the salvaging factor rests in the argument that some governments have displayed a willingness to go some way down the road to true independence by adopting 'second best' options, such as Dollarisation and monetary union. Further, as the evidence presented in section 2 demonstrates, such a move has the capacity to deliver material improvements in key macroeconomic variables. Our earlier observation regarding the existence of hybrid systems also has bearing here. For instance, it is feasible that a hybrid system consisting of a mix of the free banking and central banking systems, or free banking, Dollarisation and union, could function to capture the benefits and overcome the limitations of each. While hybrid systems like Dollarisation and union are 'second best' outcomes which, by definition, cannot be optimal, there is a potentially strong case that these 'second best' options are superior to the most widely adopted monetary system solution of central banking.

These comments aside, it must be noted that constraints of space and time confine our attention in this paper to the broadest and most obvious brush strokes in considering the implementation of free banking in South Africa. Many other, more technical, aspects of the practical operation of a modern free banking system and the political details of methods of introduction in South Africa demand consideration. For example, electronic banking adds many potential problems and solutions not applicable to free banking in the past (Bossone, 2001; Cipparone, 1999; Friedman and Macintosh, 2003; and White, 1996). Similarly, a detailed examination of the regulatory environment is needed. As the US experience demonstrated, in the absence of a sound regulatory framework, allegedly in some instances free banking degenerated into 'wild cat' banking because lax or inappropriately designed regulatory regimes led to fraud and failure of insufficiently capitalised banks (Mishkin, 2000:250). ${ }^{14}$ Thus, attention to the issue of regulation is needed (Selgin, 1996; Thomas, 2000). However, as noted, constraints of space and time mean that we must leave these considerations to future work by ourselves and others.

\footnotetext{
${ }^{14}$ For a more moderate view see Briones and Rockoff (2005.)
} 


\section{CONCLUDING REMARKS}

Of the various 'financial architecture' options considered for South Africa, informal or formal Dollarisation, extending the currency union, or a return to free banking, it is the latter that offers the greatest possibility of realising major economic gains without expanding the role of government in potentially dangerous ways or only partially addressing the moral hazards that undermine the effectiveness of central banking. That said, free banking does not preclude either informal Dollarisation or informal currency union. Indeed, as suggested above, it is possible that free banking could lead to de facto Dollarisation. Also, the system could extend beyond South Africa to embrace neighbouring countries, for instance. Thus, free banking does not preclude the monetary systems of Dollarisation and monetary union. Rather, free banking could potentially include the benefits of all these monetary regime innovations. Further, once enabling legislation or, preferably, constitutional changes have isolated the banking system from government expropriation, differential regulation, or differential taxation, the government must then pursue traditional courses of public financial management to achieve the macroeconomic objectives of full employment, growth in productivity and output and low and stable rates of price inflation.

Whilst practical impediments to the adoption of free banking in South Africa exist, we recognise that the greatest obstacle resides in challenging the international acceptance of central banking as an effective monetary system and the growing acceptance in South Africa of the view that the central bank has served, and continues to serve, the economy well and that, beyond this, a central bank regime represents the optimal form of monetary system in South Africa. However, the arguments and evidence are difficult to refute and, once free banking has been well considered as a viable alternative to central banking or, for that matter Dollarisation or monetary union, it may become more widely accepted that 'the way ahead' for South Africa's national monetary system is 'back to the future' by readopting a banking system that was abandoned almost a century ago.

\section{REFERENCES}

ALLY, R. (1994). Gold and Empire. Witwatersrand University Press: Johannesburg.

ARON, J. AND MUELBAUER, J. (2004). Review of Monetary Policy in South Africa During 1994-2004. Unpublished. Centre for the Study of African Economies.

BADER, M. AND SPINDLER, Z. (2005). Is Central Banking the Best Monetary Regime for South Africa? Free Market Foundation: Johannesburg.

BALINO, T.J., BENNETT, A., BORENSZTEIN, E. (1999). Monetary Policy in Dollari^ed Economies. Occasional Paper 171, International Monetary Fund: Washington, DC.

BARRO, R.J. AND GRILLI, V. (1994). European Macroeconomics. Macmillan: London.

BECKER, G. (1983). A Theory of Competition Among Pressure Groups for Political Influence, Quarterly Journal of

Economics, Vol. 98:371-400.

BERG, A., AND BORENSZTEIN, E. (2003). The Pros and Cons of Full Dollanzation, in SALVATORE, D., DEAN, J.W. AND

WLLLETT, T.D. (EDS, The Dollarisation Debate. Oxford University Press: New York.

BHUNDIA, A. AND GOTTSCHALK, J. (2003). Sources of Nominal Exchange Rate Fluctuations in South Africa, International

Monetary Fund Working Paper, No. 4.

BLINDER, A.S. (2004). The Quiet Revolution: Central Banking Goes Modern. Yale University Press: New Haven.

BOGOTE, Z. (2000). Official Dollanzation: Current Experiences and Issues. Cato Journal, Vol. 20: 179-213.

BOSSONE, B. (2001). Do Banks have a Future? A Study of Banking and Finance as We Move into the Third Millennium, Journal of Banking and Finance, Vol. 25: 2239-2276.

BRIONES, I. AND ROCKOFF, H. (2005.) Do Economists Reach a Conclusion on Free Banking Episodes?, Economic Journal Watch, Vol. 2: 279-324.

BROZ, J. L. (1998). Origins of the Federal Reserve System: International Incentives and the Domestic Free-Rider

Problem, International Organisation, Vol. 53: 39-70. 
CHU, K.H. (1996). Is Free Banking More Prone to Bank Failures than Regulated Banking, Cato Journal, Vol. 16(1): 48-61. CIPPARONE, M. (1999). The Role of the Central Bank in the Growing Industry of Internet Payments. http://www.vi.unibe.ch/staff/berentsen/folderl.htm.

COHEN, B. (2003). Monetary Union: The Political Dimension in SALVATORE, D., DEAN, J.W. AND WILLETT, T.D. (EDS), The Dollarisation Debate. Oxford University Press: New York.

CURRIE, L. (1935 [2004a]) 'The Relation of Government to Monetary Control, reproduced m Journal of Economic Studies, Vol. 31: 267-69.

(1935 [2004b]).'The Objectives of the Banking Bill of 1935': Federal Reserve Board Memoranda (1935), reproduced $m$ Journal of Economic Studies, Vol. 31: 280-88.

DEKOCK, G. (1954). A History of the South African Reserve Bank (1920-52). J.L. Van Schaik: Pretoria:

DEMERTZIS, M., HALlETT, A. H. AND VlEGI, N. (2004). An Independent Central Bank Faced with Elected Governments, European Journal of Political Economy, Vol. 20(4): 907-922

DE VANSSAY, X. (2002). Monetary Unions: A Historical Perspective, in CROWLEY, P. Before and Beyond EMU. Routledge: New York.

DELONG, B. (2004). BradDeLong's Web Journal.

http://www.j-bradford-delong.net/movable_type/archives/000866.html.

Du PLESSIS, S. (2005). The Democratic Deficit and Inflation Targeting, South African Journal of Economics, Vol. 73(1):93-

104.

DOWD, K. (ED.) (1992). The Experience of Free Banking. Routledge: New York.

FRANKELj.A. (1999) No Single Currency Regime Is Rightfor All Countries or At All Times. NBER Working Paper No. 7338.

FRANKEL, J.A. AND ROSE, A.K. (1998). The Endogeneity of the Optimum Currency Area Criteria, The Economic Journal,

Vol. 108(July):1009-1025.

FRIEDMAN, D. AND MACINTOSH, K. (2003) Technology and the Case for Free Banking, in FOLDAVY, F.E. AND KLEIN, D.B. (EDS), The Halflife of Policy Rationales: How New Technology Affects Old Policy Issues. Cato Institute: Washington, D.C. FRIEDMAN, M. (1982. Monetary Policy: Theory and Practice, Journal of Money, Credit and Banking, Vol. 14: 98-118. GREENSPAN, A. (2005). Reflections on Monetary Policy 25 Years after October 1979: Chairman's Remarks, Review, Vol. 87(2):137-138.

GRUBEL, H. (2003). Canada's Exercise of National Monetary Sovereignty: Beneficial or Harmful? Paper presented at the conference 'Britain and Canada and their Large Neighbouring Monetary Unions, University of Victoria, Canada, October 17-18.

-------(2004). What Benefits from Monetary Sovereignty for a Small Country? A Case Study of Canada. Conference Paper at 'Asymmetries m Trade and Currency Arrangements in the 21st Century' at the Deutsche Bundesbank, Frankfurt, July 2004.

GWARTNEY, ]., SCHULER, K. AND STEIN, R (2001). Achieving Monetar Stability at Home and Abroad, Cato Journal, Vol. 21: 183-203.

HANKE, S. (1999). Reflections on Exchange Rate Regimes, Cato Journal, Vol. 18: 335-344.

------(2001). Argentine Endgame: Couple Dollarisation with Free Banking, Cato Foreign Policy Briefing Paper No. 67.

------ (2003a). A Dollanzation/Free-Bankmg Blueprint for Argentina, in D. SALVATORE, DEAN, J.W. AND WlLLETT, T.D. (EDS), The Dollarisation Debate. Oxford University Press: New York.

-(2003b). The Argentine Straw Man: A Response to Currency Board Critics. Cato Journal, Vol. 23: 47-57.

HAYEK, F. (1988). The Fatal Conceit: The Errors of Socialism. Routledge: New York.

HEFEKER, C. (1997). Interest Groups and Monetary Integration: The Political Economy of Regime Change Choices. Westview Press: New York.

HENRY, J.A. (1963). The First Hundred Years of the Standard Bank. Oxford University Press: London.

HICKSON, C.R AND TURNER, J.D. (2004). Free Banking and the Stability of Early Joint-Stock Banking, Cambridge Journal of Economics, Vol. 28(6):903-919.

KHAMFULA, Y. AND MENGSTEAB, T. (2004). South Africa and Southern African monetary Union: A Critical Review of Sources of Costs and Benefits, South African Journal of Economics, Vol. 72(l):37-49.

MBOWENI. T.T. (2004) Challenges of Central' Banking in Africa. Conference Speech, Lusaka, Zambia, 5 August.

MCCARTHY, C. (2003). The South African Customs Union in Transition, African Affairs, Vol. 102:605-630.

MELTZER, A.H. (2005). Origins of the Great Inflation, Review, Vol. 87(2):145-176.

MISHKIN, F.S. (2000). The Economics of Money, Banking and Financial Markets, Sixth Edition. Addison-Welsey: Boston.

MOLLENTZE, S. L. (2000) Monetary Policy m South Africa on the Threshold of a New Era, South African Journal of

Economic and Management $S$ ciences, $N$ ol. SS2: S1-S50.

MORENO-VrLLALAZ, J. L. (1999). Lessons from the Monetary Experience of Panama: A Dollar Economy with Financial

Integration, CatoJoumal,Nol. 18:421-440.

MURPHY, L., ARTANA, D. AND NAVAJAS, F. (2003). THE ARGENTINE ECONOMIC CRISIS, CATO

JOURNAL, VOL. 23(SPRING/SUMMER):23-28

NOFSINGER, J.R. (2001). Investment Madness: How Psychology Affects Your Investing and What To Do About It. Prentice Hall: Upper Saddle River, New Jersey.

ROLNICK, AJ. AND WARREN, EW. (1983). The Free Banking Era: New Evidence on Laissez-Faire Banking, American

Economic Review, Vol. 73:1080-1091.

ROSE, A.K. (2000). One Money, One Market: Estimating the Effect of Common Currencies on Trade, Economic Policy, Vol. 15(30):7-46.

SALVATORE, D., DEAN, J.W. AND WILLETT, T.D. (EDS), (2003.) The Dollarisation Debate. Oxford University Press: New 
York.

SCHULER, K. (2001). Note Issue by Banks: A Step toward Free Banking in the United States? Cato journal, Vol. 20(3): 453-465.

------(2003a). Why Ecuador is Not Another Argentina, Revista Mipymes Ecuador 1 (2),

www. do lanz atio ne nla s am e nc a s. com.

(2003b). What Use is Monetary Sovereignty? in D. SALVATORE, DEAN, J.W. AND WILLETT, T.D. (eds), The Dollarisation Debate. Oxford University Press: New York.

(2005). Ignorance and Influence: U.S. Economists on Argentina's Depression 1998-2002, Economic Journal Watch, Vol. 2: 234-278.

SELGIN, G. (1996). Banking Deregulation and Monetary Order. Routledge: New York.

SELGIN, G. AND WHITE, L. (1994). How Would the Invisble Hand Handle Money? Journal of Economic Literature, Vol. 22: 1718-1749.

----- (2005). Credible Currency: A Constitutional Perspective, Constitutional Political Economy, Vol. 16: 71-83.

SPINDLER, Z.A. (2004a). Public Choice Perspectives on Monetary Regimes, South African Journal of Economics, Vol. 72(l):5082.

---- (2004b). The Deconstruction of Privatisation. Free Market Foundation: Johannesburg.

SPINDLER, Z A. AND DE VANSSAY, X. (2000). The Public Choice of Cartels, Journal of Public Finance and Public Choice, Vol. 18:3-22.

STAMP, D. (2002). Market Prophets: Can Forecasters Predict the Financial Future? Pearson Education: London.

STOCKMAN, A. (2000). Exchange Rate Systems in Perspective, Cato Journal, Vol. 20(1):115-122.

THOMAS, H. (2000). A Proposal to Deregulate Banking, Cato Journal, Vol. 20:237-253.

TIMBERLAKE, RH. (2005). Gold Standards and the Real Bills Doctrine in U.S. Monetary Policy, Economic Journal Watch,

Vol. 2: 196-233.

VAUBEL, R (1997). The Bureaucratic and Partisan Behavior of Independent Central Banks: German and International

Evidence, European Journal of Political Economy, Vol. 13: 201-224.

VERCUIL, D. (2002). Bank Failures, www.derebus.org.za/archives/2002May.

WEEMTRAUB, R.E. (1978). Congressional Supervision of Monetary Policy, Journal of 'Monetary Economics, Vol. 4: $341-362$.

WESSELS, G.M. (2003). The Suitability of Dollarisation as an Exchange Rate Regime for South Africa. Discussion paper.

WHITE, L.H. (1996). The Technology Revolution and Monetary Evolution, www.cato.org/moneyconf/14mc-7hmtl.

-----(2003). Currency C 